\title{
Supporting students in higher education in transforming their thesis into a scientific article
}

\author{
Kristina Areskoug Josefsson ${ }^{1,2,3}$ and Annika Nordin ${ }^{3}$ \\ ${ }^{1}$ VID Specialised University, Faculty of Health Studies, Sandnes, Norway; ${ }^{2}$ Department for \\ Behavioural Sciences, Oslo Metropolitan University, Oslo, Norway; ${ }^{3}$ School of Health and Welfare, \\ Jönköping Academy for Improvement of Health and Welfare, Jönköping University, Jönköping, \\ Sweden
}

According to our experience from education in health and welfare, there are increased expectations in academia for students to publish their work as scientific international articles. Reasons and motivation for transforming the thesis to a scientific article vary; however, it is essential to understand that the work includes substantial revision to meet the requirements of a scientific article. We have long experience of teaching in higher education and have supported students from various educational programs in health and welfare to publish their theses as articles in scientific journals. This demands time, engagement and competence from both supervisors and students, demands that to our knowledge rarely are acknowledged in higher education organisations. A coherent guide on how to support students aiming for publication would have been helpful, and this article is anchored in our experiences and reflections on this matter. This article highlights eight preparatory reflective questions and presents a guide for supervisors in supporting actions for the transformation of a thesis to an article.

Keywords: academic writing, academic guidance, higher education, scientific publishing, supervisor support

\section{INTRODUCTION}

In academia, expectations that students in health and welfare will publish their work as scientific international articles are increasing, according to our experiences as supervisors in this field. This article presents advice for supervisors on how to guide students in transforming their thesis to a scientific article. Supervisors or students can initiate the transformation of a thesis, aiming to present the student's research to a wider audience or to encourage learning for a future academic career. To meet publication expectations, students need guidance. Supervisors' and students' joint scientific publishing is, however, scarcely described in the scientific literature (Jeppson \& Haglund, 2019), and the prevalence of co-writing varies between disciplines.

We have long experience of teaching in higher education and have supported students from various educational programs in, i.e., medicine, rehabilitation, nursing and social work to publish their theses in scientific journals. This demands time, engagement and competence from both supervisors and students, demands that to our knowledge rarely are acknowledged in higher education organisations. A coherent guide on how to support students aiming for

Correspondence to: kristina.areskoug@vid.no

Artiklar och reflektioner är kollegialt granskade. Övriga bidragstyper granskas av redaktionen. Se https://hogreutbildning.se ISSN 2000-7558

(C)2021 Kristina Areskoug Josefsson and Annika Nordin. This is an Open Access article distributed under the terms of the Creative Commons Attribution-NonCommercial 4.0 International License (https://creativecommons.org/licenses/by-nc/4.0/), allowing third parties to share their work (copy, distribute, transmit) and to adapt it, under the condition that the authors are given credit, that the work is not used for commercial purposes, and that in the event of reuse or distribution, the terms of this license are made clear.

Citation: Josefsson, K. A. \& Nordin, A. (2021). «Supporting students in higher education in transforming their thesis into a scientific article», Högre utbildning, 11(2), 37-45. http://dx.doi.org/10.23865/hu.v11.2627 
publication in scientific journals would have been helpful, and this article is anchored in our experiences and reflections on this matter.

In this article, the notion "thesis" will be used, even though it has various meanings. In this article, "thesis" refers to the final mandatory essay for a bachelor's and master's degree. A thesis can be written by a single student or by pairs or groups of students, depending on academic level and university requirements, and its content may be suitable for both scientific and professional publications. Bearing the requirements of a scientific article in mind, the motivation of the student for transforming a thesis has to be clear. The reasons can be complex and may encompass both intrinsic and extrinsic motivational factors (Resta et al., 20IO). Students can, e.g., believe the knowledge gained will create positive change, lead to new innovations or promote a future career. For higher education, students' and supervisors' joint publishing can introduce students to the scientific community of practice and exemplify how the education is anchored in research (Jeppson \& Haglund, 2019). Whatever the motivation for transforming the thesis, it is essential to understand that the work includes substantial revision to meet the requirements of a scientific article (Kennedy, 20I8; O’Halloran \& Doody, 20I4).

The first key to successfully spreading new knowledge is to target the right audience (O'Halloran \& Doody, 20I4; Turbek et al., 20I6). Thus, students must resolve several questions regarding the audience, namely: who this audience is, why it has been identified as the target audience and how it can be reached. Depending on their motivation and aim, students may decide it is better to consider other outreach methods than writing a scientific article. The possibilities include podcasts, YouTube, blog posts and vlogposts, which are new media often reaching wide audiences that are less likely to read a specific scientific journal. Poster presentations and oral presentations at professional, scientific or user conferences are other options. An informed decision on audience and outreach method will increase both the impact and the efficacy of performed actions and work. Our experience is that different views on outreach methods and a lack of a mutual understanding can lead to conflicts, misunderstandings or decreased engagement in the publication process. By prompt and thorough address of such problems, we have learned that successful collaboration is possible. We have also experienced the importance of clarifying for students how the transformation process largely exceeds the mandatory supervisor commitment in undergraduate education.

There are several publications on how to write a scientific article (Hoogenboom \& Manske, 20I2; Kennedy, 20I8; Rogobete, 20I6; Turbek et al., 20I6). However, even though students are increasingly encouraged to publish, guidance on how they can prepare for this is lacking (Resta et al., 20Io). This is a problem, since inexperienced writers risk producing ineffective writing, acquiring poor writing habits and becoming resistant to criticism of the manuscript (Hoogenboom \& Manske, 20I2).

This article gives support for supervisors by presenting eight preparatory reflective questions and a guide for students supporting actions for the transformation. The article also suggest how supervisors can be supportive during all steps of the transformation, including pedagogy, ethics, manuscript revisions and reorientation if the article is rejected from the aspired journal.

\section{EIGHT PREPARATORY REFLECTIVE QUESTIONS}

Reflection is a premise for learning and depends on the conditions provided for it (Colomer, Serra, Canabate, \& Bubnys, 2020). Students rarely have knowledge of the challenges prior to the actual process of re-writing, and supervisors can offer the following eight preparatory questions as a condition for reflection and thus help them take the first steps towards publication. 
We have found that going through these questions with students is well-invested time, where some students quickly refrain from the transformation idea and others gain a clear direction and understanding of the process.

\section{What is the level of interest?}

The thesis may have created interest among fellow students and might have been given a high grade, but this does not necessarily mean that editors will see the thesis in the same way. By choosing the target journal prior to writing the manuscript, the identification of potential readers and understanding of their needs will be clearer for authors. Position of the intended manuscript is crucial (Kennedy, 20I8). Therefore, it is important to know the targeted audience and whether the knowledge gained in the thesis is novel and interesting for that audience. Timeliness, relevance, prevalence and importance should be acknowledged. We have experienced students who failed with the transformation of their theses because they persisted on aiming for too high-impact journals or journals whose scope was not in line with their theses. It is therefore important that students acquire an early understanding of the diversity of international-quality journals and have reasonable expectations on the level of interest of their work.

\section{Who are the owners of the thesis?}

Theses are sometimes written by pairs of students, and in such cases, it is crucial to have an early agreement regarding the ownership of the work. If one of the students has no interest in participating in the re-writing, it is not self-evident that the other student can publish alone. When written in pairs, the original thesis is a shared work. There can be legal copyright requirements to consider, depending on country and university, as well as ethical considerations connected to ownership. In some cases, there is supervisor involvement throughout the thesis, and then the supervisor should also be involved in the decision of whether to try to publish the thesis as a scientific article.

At some universities, students publish their thesis with open access in the university's directories, and additional publication of the same text risks being considered as self-plagiarism or text-recycling (Pierson, 2017).

\section{Does the thesis meet the requirement of methodological rigour?}

The demands for methodological rigour are high in scientific articles, and it is important to consider whether the thesis meets these requirements. A scientific article describing original research or a literature review should provide information enabling assessment of the logic of the chosen method, the quality of the work and the study's reproducibility. If the thesis does not meet these requirements, previous work must be revised. To our experience students often have difficulties recognising that their theses do not correspond the methodological demands of a scientific article. In such cases it has been helpful to be clear about this and to suggest methodological readings. Furthermore, it has been fruitful to encourage students to compare the methodology in their thesis with the methodology in articles in the journal they are aiming for.

\section{What are the central ethical considerations?}

Most scientific journals in health and welfare demand presentation of ethical approval prior to publishing (Wu, Howarth, Zhou, Hu, \& Cong, 2019). Thus, if students have the ambition to transform their thesis into an article, it is important to ensure that the work adheres to research ethics and is legally and ethically sound to publish. We have repeatedly noticed students being unaware of the differing ethical requirements of student work and scientific articles. Due to 
Swedish legislation, ethical approval is required in many cases, but undergraduate theses are not covered by the law since they ordinarily are not intended for scientific publication (SFS 2003:460). This means that ethical approval may be lacking and restricting the opportunity for publication of theses. Ethical approval cannot be sought after the study has started in Sweden, and therefore students need to be knowledgeable about the legislation when they start their project. Consequently, supervisors need to assist students' understanding of ethical requirements of scientific articles, but also in their local context.

Who are the authors of the scientific manuscript?

There are requirements concerning who can and should be called an author of a scientific article, depending on the contribution to the work (Pierson, 2017). In health and welfare articles it is common that the first author has the main responsibility for the manuscript and the last author often has a more supervisory role in the writing process (Bhattacharya, 20IO). It is not uncommon that scientific groups have disagreements over authorship and expectations during the writing process, so clarity from the start saves trouble (Puskás \& Jeppsson, 20I7; Resta et al., 20IO). Unethical authorship issues, like pressure concerning the order of authors, are not unknown to students in Sweden and Norway (Hofmann, Helgesson, Juth, \& Holm, 20I5). One way to prevent post-publication authorship disputes is to have clear agreements on contributions and preparatory work between the authors beforehand (Pierson, 2017). The Vancouver protocol also provides clarity on how authors' scientific contributions should be acknowledged (International Committee of Medical Journal Editors). When there are several authors, a project plan, including time frames and tasks, together with open communication among the authors, will facilitate the work process. To our experience, preparatory work to prevent authorship disputes has rarely (if ever) been brought forward by students. Thus, supervisors have the ethical responsibility to help students see the importance of clear authorship agreements prior to transforming the thesis.

\section{Are there enough resources?}

Scientific writing takes time and substantial effort (Hoogenboom \& Manske, 20I2; Kennedy, 20I8). Thus, students must make sure they allocate enough time for the work. A realistic timeplan, including time for discussions with those involved and making choices regarding the next step of the process, is essential. It is also a matter of competence, knowledge of writing and revision as well as knowledge of the research field. One single author rarely possesses the qualifications and competencies needed when it is the first scientific manuscript he or she has written. In some cases, a mentor can support the development of scientific writing skills (Tofthagen $\&$ McMillan, 20I8). Authors can also invite co-authors in order to gain perspectives on data or to share the work load of writing (Tofthagen \& McMillan, 20r8).

A good work relationship is a prerequisite for joint publishing (Jeppson \& Haglund, 2019). Consequently, both parties need to honestly examine the work relation and work demands prior to collaboration. This is especially important since the students do not have access to seminars and networks supporting reflection and learning like $\mathrm{PhD}$ students have. It is easy to be carried away by students' enthusiasm, which risks downplaying the importance of critically reviewing the prerequisites for the project. Supervisors may feel obliged to partake in the transformation process, despite an already overwhelming workload. Our experience is that it is helpful to let the decision take some time and to jointly develop a time- schedule for the complete transformation process. 
Are the language skills sufficient for publication?

Authors often receive criticism concerning their language from reviewers and editors. There is also a higher risk of rejection if the text is difficult to understand. A manuscript will probably need language revision even when students choose to publish in their first language. Make sure the text is of high quality, accurate and clear (Hoogenboom \& Manske, 20I2). We have learned to clarify that a language proof service doesn't include complete translation of texts and that the department rarely budgets for translations of student work to scientific publications. On some occasions limited competence in English has been a hindering factor for students aiming for publication in international journals.

\section{What are the expenditures and funding sources?}

There are expenditures involved in publishing articles, such as article process charges, proofreading costs, and fees for coloured figures in the manuscript. The costs vary greatly between journals. Preparation by calculating potential expenditures and exploring funding sources is suggested early in the transformation. Most of our students are also professionals, and we have learned they need encouragement to ask for financial publication support from their employers. We have also noted students not knowing if their organisations might have research and development departments willing to take on the publication costs.

\section{A STUDENT GUIDE SUPPORTING THE TRANSFORMATION}

The transformation of a thesis into a scientific article can be experienced as a meaningful and rewarding task (Resta et al., 20I0; Tofthagen \& McMillan, 20I8). Thus, when students have presented a clear understanding of the eight preparatory reflective questions and feel ready to get started, supervisors can add clarity by using $A$ student guide - Supporting the transformation of a thesis into a scientific article (Table I). Each step of the guide provides value for the next step, and for the transformation to be efficient, it is important that all co-authors have a shared understanding of the merit of the writing process itself. In addition to the guide, supervisors must state their own abilities to contribute, a decision often based on faculty culture, previous experience and already existing workload. Supervisors should consider the pedagogical demands of each step and potential ethical dilemmas related to the steps.

Table I. A student guide - Supporting the transformation of a thesis into a scientific article

\begin{tabular}{|l|l|l|}
\hline I & $\begin{array}{l}\text { Define audience and } \\
\text { type of article }\end{array}$ & $\begin{array}{l}\text { Consider the audience for the article. } \\
\text { Choose an appropriate definition for the type of article: original article, review article, } \\
\text { short communication, editorial or professional reflection. }\end{array}$ \\
\hline 2 & Decide on co-authors & $\begin{array}{l}\text { Evaluate own knowledge and capacity to write. } \\
\text { If co-authors are included, make a time plan with agreements on expectations regarding } \\
\text { role and engagement in writing. }\end{array}$ \\
\hline 3 & $\begin{array}{l}\text { Decide journal and } \\
\text { funding }\end{array}$ & $\begin{array}{l}\text { Read scope of suitable journals and previously published work from these journals. } \\
\text { Contact a librarian for suggestions and to avoid predatory publishers. } \\
\text { Discuss funding possibilities. } \\
\text { Decide journal and read author guidelines. }\end{array}$ \\
\hline 4 & $\begin{array}{l}\text { Develop "raw" } \\
\text { manuscript }\end{array}$ & $\begin{array}{l}\text { Build a draft by following author guidelines. } \\
\text { Fill in relevant text from the thesis. } \\
\text { Look for gaps where additional text is needed. } \\
\text { Add preliminary text to relevant headings and subheadings. }\end{array}$ \\
\hline
\end{tabular}


42 Kristina Areskoug Josefsson \& Annika Nordin

Table I. (Continued)

\begin{tabular}{|c|c|c|}
\hline 5 & $\begin{array}{l}\text { Engage with } \\
\text { co-authors }\end{array}$ & Send the "raw" manuscript to co-authors for review, to add text and critical comments. \\
\hline 6 & $\begin{array}{l}\text { Connect to research } \\
\text { field }\end{array}$ & $\begin{array}{l}\text { Continue reading in the targeted journal and the research field. } \\
\text { Consider if an additional literature review is needed. } \\
\text { Add new references of value. }\end{array}$ \\
\hline 7 & Review the disposition & $\begin{array}{l}\text { Review the disposition of the manuscript to make sure there is a suitable quantity of text } \\
\text { under each heading. It is common that the introduction is too lengthy in comparison with } \\
\text { sections covering the results and discussion. }\end{array}$ \\
\hline 8 & $\begin{array}{l}\text { Develop a "good } \\
\text { enough" manuscript }\end{array}$ & $\begin{array}{l}\text { Continuously send the manuscript to co-authors for comments and revisions. Consider } \\
\text { using tracked changes and a set order in which co-authors work on the manuscript. } \\
\text { Repeat Steps 5-8 until all authors agree the manuscript is "good enough". }\end{array}$ \\
\hline 9 & Do audience check & $\begin{array}{l}\text { Send the "good enough" manuscript to a colleague, a targeted reader or professional who } \\
\text { has not previously read the work and ask for constructive criticism on readability, level of } \\
\text { interest and clarity of thought of the manuscript. }\end{array}$ \\
\hline IO & $\begin{array}{l}\text { Develop "nearly- } \\
\text { finished" manuscript }\end{array}$ & Revise the manuscript with the co-authors, based on feedback from Step 9. \\
\hline II & Improve language & $\begin{array}{l}\text { Ask someone external from the co-author group to edit the language. Consider a profes- } \\
\text { sional language proofreading service. } \\
\text { Revise according to language feedback. }\end{array}$ \\
\hline I2 & $\begin{array}{l}\text { Do quality check of } \\
\text { "final" manuscript }\end{array}$ & $\begin{array}{l}\text { Double-check that author guidelines have been followed. } \\
\text { Seek approval from all co-authors of the "final" manuscript for submission. }\end{array}$ \\
\hline $\mathrm{I} 3$ & $\begin{array}{l}\text { Prepare manuscript for } \\
\text { submission }\end{array}$ & $\begin{array}{l}\text { Save each file separately (figures, tables, title page are often up-loaded as separate files) and } \\
\text { carefully follow the instructions for authors from the journal to safeguard the double-blind } \\
\text { review process. } \\
\text { Write a cover letter for submission. } \\
\text { Suggest reviewers of the manuscript to the journal if required. } \\
\text { Note ORCID numbers for co-authors. }\end{array}$ \\
\hline I4 & Submit the manuscript & $\begin{array}{l}\text { Make sure the internet connection is stable. } \\
\text { Create an author account with the publisher or journal. } \\
\text { Allocate sufficient time for the submission process, and work without interruptions. } \\
\text { Save the submission notification and share all submitted documents with co-authors. }\end{array}$ \\
\hline I5 & $\begin{array}{l}\text { Follow the review } \\
\text { process }\end{array}$ & $\begin{array}{l}\text { The review process can be lengthy, so make it a habit to log in to the author account to } \\
\text { view the updated information. } \\
\text { The review process is often double-blind, meaning neither the author nor the reviewer } \\
\text { knows who the other is. }\end{array}$ \\
\hline I6 & $\begin{array}{l}\text { Complete revision and } \\
\text { resubmission }\end{array}$ & $\begin{array}{l}\text { Follow the feedback from reviewers/editors and pay attention to the timeliness of } \\
\text { re-submission requirements. }\end{array}$ \\
\hline I7 & $\begin{array}{l}\text { Get published and } \\
\text { celebrate }\end{array}$ & $\begin{array}{l}\text { Celebrate when the manuscript is accepted for publication and pay attention to require- } \\
\text { ments for proofreading, author agreement statements and communication with the } \\
\text { publisher. }\end{array}$ \\
\hline
\end{tabular}

\section{SUPERVISOR SUPPORT DURING REVISION}

The supervisor's role in the transformation and publication process is crucial but demands time and engagement. If the article becomes published it is of merit not only for the student but for the supervisor and the university as well. There are examples of supervisors aiming to merit themselves more than contributing to the students reaching their potential author ambitions (Puskás \& Jeppsson, 20I7). So it is important that the supervisor has good intentions and is not aiming to merit himself or herself at the expense of the student. If the article does not get 
published, the value of the invested effort may seem less rewarding, even if all involved have learned from the process.

For students considering an academic career, the transformation of the thesis can be a first introduction to academic work and the scientific community. The length of the review process varies greatly between journals, but eventually the corresponding author will be notified. The rejection rate of submitted manuscripts is high, and authors must be prepared for both rejection and revision. The supervisors' role in assisting and supporting students during the whole revision period is crucial. Just like students, supervisors can feel the burden of revision work and the emotional stress of not having reached the set publication goal. All reviewer comments have to be addressed in a manuscript revision. A rigorous approach ensures all comments are properly addressed and simplifies for the editor and reviewers. It is possible to have revised a manuscript several times and still get rejected. If the article is rejected the editor might suggest another journal more suitable for the manuscript. Otherwise, students must find a new journal, i.e., by returning to Steps I and 3 of the Guide (Table I). The chosen outreach method can also be considered, bearing in mind that it is rewarding to publish the findings through other media as well.

The transformation described in this article may seem lengthy and tedious to students, especially since the university has already approved the theses. However, the demands concerning theses differ from those for scientific articles, and supervisors need to clarify the work required for the transformation. The pedagogical support needed in the revision process is timeconsuming and according to our experience often more demanding, considering that students have less optimism in this phase.

Considerations on how to finish the transformation process without reaching publication can pose ethical dilemmas. Students' and supervisors' motives to proceed or disrupt the transformation proceeding must be made clear, and to avoid unethical pressure on either part we suggest involvement of colleagues at the department in the discussions.

The repeated revision process demands skills in both writing and reflection. Criticism and comments can feel hard, and supervisors have a pedagogical task in helping students understand that the comments are important to improve the manuscript in terms of direction, detail or language. Supervisors can also help students to acknowledge the voluntary work that is done by reviewers and to appreciate the time taken by them to create opportunities for improving the manuscript and thus increasing the likelihood of acceptance. Students, for their part, need to be motivated and positive towards the review and writing process to see the transformation as a learning journey towards becoming a scientific writer (O’Halloran \& Doody, 20I4).

This article is based on our previous work experience in health and welfare education; however, the reflective questions and the guide are general and therefore useful in other disciplines with similar challenges as well. To test and to provide enhanced knowledge of the usefulness of the questions and the guide, we intend to involve students interested in publication and to collaborate with the faculties where we currently work. We also encourage others to test the questions and the guide in practice.

\section{CONCLUDING REMARKS}

Attempting to transform a thesis into a scientific article requires thorough work, demanding pedagogical skills and ethical considerations, which can be facilitated by a step-by-step work process and reflective guidance. Successful publication is rewarding for both supervisors and students. The work process itself can be rewarding even if the process does not immediately lead to publication, due to the learning and increased scientific writing skills it brings forward. The 


\section{Kristina Areskoug Josefsson \& Annika Nordin}

shared work experience can be enhanced by clarity on expectations and prerequisites. Supervisors play an important role, as do the eight reflective questions, the guide and the suggestions regarding how to be supportive during the revision.

\section{ABOUT THE AUTHORS}

Kristina Areskoug Josefsson is Professor in Public Health and Rehabilitation at VID Specialized University and Associate Professor in Quality Improvement and Leadership in Health and Welfare at Jönköping University and at Oslo Metropolitan University. Areskoug Josefsson teaches mainly at the master program in Citizenship and Co-operation at VID Specialized University. Areskoug Josefsson's research is in learning outcomes, public health and rehabilitation.

Annika Nordin is Assistant Professor in Quality Improvement and Leadership in Health and Welfare at Jönköping University, where Nordin teaches at the master program in Quality Improvement and Leadership in Health and Welfare and the bachelor program for medical secretaries. Nordin's research is in learning outcomes, co-production and quality improvement.

\section{REFERENCES}

Bhattacharya, S. (2010). Authorship issue explained. Indian Journal of Plastic Surgery, 43(2), 233-234. https://doi.org/ı0.4103/0970-0358.73482

Colomer, J., Serra, T., Canabate, D., \& Bubnys, R. (2020). Reflective learning in higher education: Active methodologies for transformative practices. Sustainability, I2(9), 3827.

Hofmann, B., Helgesson, G., Juth, N., \& Holm, S. (2015). Scientific dishonesty: A survey of doctoral students at the major medical faculties in Sweden and Norway. Journal of Empirical Research on Human Research Ethics, Io(4), 380-388. https://doi.org/IO.II77/I556264615599686

Hoogenboom, B. J., \& Manske, R. C. (20I2). How to write a scientific article. International Journal of Sports Physical Therapy, 7(5), 512-5I7.

International Committee of Medical Journal Editors. Recommendations for the conduct, reporting, editing, and publication of scholarly work in medical journals, "the Vancouver protocol". Retrieved from http://www.icmje.org/

Jeppson, F., \& Haglund, J. (2019). Sampublicering med studenter-ett sätt att stärka forskningsanknytningen i lärarutbildningen. Högre Utbildning, 9(I), 98-III.

Kennedy, M. S. (2018). Journal publishing: A review of the basics. Seminars in Oncology Nursing, 34(4), 36I-37I. https://doi.org/Io.IoI6/j.soncn.20I8.09.004

O'Halloran, M., \& Doody, O. (20I4). To write or not to write: A nurse's account of writing for publication. British Journal of Nursing, 23(IO), 524-527. https://doi.org/I0.I2968/bjon.20I4.23.10.524

Pierson, C. (20I7). Avoiding ethics pitfalls in publishing: A perspective from COPE. Oral Diseases, $23(4)$, 4I6-419. https://doi.org/IO.IIII/odi.I2539

Puskás, T., \& Jeppsson, F. (20I7). Om forskarhandledningens mål, samförfattarskap och meritering: Några dilemman inom det utbildningsvetenskapliga fältet. Högre utbildning, 7(2). https://doi.org/I0.23865/ hu.v7.1062

Resta, R. G., McCarthy Veach, P., Charles, S., Vogel, K., Blase, T., \& Palmer, C. G. S. (2010). Publishing a master's thesis: A guide for novice authors. Journal of Genetic Counseling, I9(3), 217-227. https://doi. org/I0.1007/sio897-009-9276-2

Rogobete, A. F. (20I6). Basic guidelines in writing a scientific article. Journal of Interdisciplinary Medicine, $I(\mathrm{I})$, 7. https://doi.org/IO.I515/jim-2016-0002

SFS 2003:460. Lag om etikprovning av forskning som avser människor. https://www.riksdagen.se/sv/ dokument-lagar/dokument/svensk-forfattningssamling/lag-200346o-om-etikprovning-av-forskning-som_sfs-2003-460 
Tofthagen, C., \& McMillan, S. C. (2018). An Academic Perspective on Publishing in Oncology Nursing. Seminars in Oncology Nursing, 34(4), 393-40I. https://doi.org/I0.Ior6/j.soncn.20I8.09.008

Turbek, S. P., Chock, T. M., Donahue, K., Havrilla, C. A., Oliverio, A. M., Polutchko, S. K., ... Vimercati, L. (2016). Scientific Writing Made Easy: A Step-by-Step Guide to Undergraduate Writing in the Biological Sciences. The Bulletin of the Ecological Society of America, 97(4), 417-426. https:// doi.org/IO.IOO2/bes2.I258

Wu, Y., Howarth, M., Zhou, C., Hu, M., \& Cong, W. (2019). Reporting of ethical approval and informed consent in clinical research published in leading nursing journals: a retrospective observational study. BMC Medical Ethics, 20(I), 94. https://doi.org/IO.II86/sI29IO-OI9-043I-5 